\title{
Seventh-Century Ireland as a Study Abroad Destination
}

\author{
Colin Ireland
}

Beaver College, Dublin, Ireland

\section{Introduction}

As a modern-day International Educator you might easily believe that you are involved in a pioneering endeavor. Would it surprise you to learn that you had predecessors in Ireland thirteen hundred years ago? Did you know that the Emerald Isle attracted swarms of eager foreign students, principally from England, to its monastic schools as early as the seventh century? Monastic schools were the universities of medieval Europe. In this article I will portray-from the scanty records that survive-scenes from the life of these "study abroad students" in Ireland's early medieval centers of learning.

Trying to reconstruct the society of the early Middle Ages from surviving records is a bit like putting together a jigsaw puzzle when $90 \%$ of the pieces are missing. Everyone stands around and argues about how the remaining $10 \%$ of the pieces fit, or even if they belong to the particular puzzle at all.

In order to reconstruct the life of "study abroad students" in seventh-century Ireland I rely primarily on three sources. The first two sources are the English churchmen Aldhelm and Bede. Aldhelm (d.709), abbot of Malmesbury and later bishop of Sherborne, was the first AngloSaxon man of letters. Fortunately, at least two letters by him to AngloSaxon students who studied in Ireland survive. Bede (d.735), a priest at Wearmouth-Jarrow, was the greatest of the Anglo-Saxon men of letters. He wrote a history of the Anglo-Saxon Church (Historia Ecclesiastica (HE)), cited frequently in this article, which often notes the relationships between the English and the Irish in the seventh century. As English cler- 
ical scholars, Aldhelm and Bede are eager to promote the Church of Rome and Anglo-Saxon England's role in its growth. Nevertheless, they frequently acknowledge the Irish contribution to English Church history and Anglo-Saxon learned culture. Bede tells us, for example, that Irish schools provided English students with free books and free instruction. My third major source is the Hisperica Famina1 "Western Sayings," a cryptic Latin text written in Ireland by, or about, foreign students sometime probably between c.650 and c.665. The Hisperica Famina are secular in tone and give us our most intimate glimpse into the life of "study abroad students" in early Ireland.

Nowadays many students find Ireland an attractive study abroad destination because it is an English-speaking country. We admire AngloIrish literature and such Irish writers as Yeats, Joyce, Beckett, and Shaw, all of whom wrote in English. Yet Ireland's equally rich Gaelic heritage is often as obscure as the Latin Middle Ages. Many of Ireland's literary treasures remain hidden because they were written either in Irish (Gaelic) or in Latin. The current worldwide importance of English has made it accepted as the language of higher education, just as Latin was during the Middle Ages. Because we live and work in an English-speaking world, a secondary purpose of mine has been to highlight, where appropriate, Irish influence on Early English (Anglo-Saxon) learned culture, even where that learning has been conveyed through Latin.

Ireland is the first Western European country to create an extensive literature using its own vernacular, Irish, in addition to using Latin. Literature in Irish placed as much emphasis on secular as on religious topics. ${ }^{2}$ Nevertheless, Latin, as the language of the Church, was the primary intellectual language of the Middle Ages. During this period, Irish scholars studied and, in turn, taught those Christian Latin authors deemed most important by the Church, while they also created an extensive Hiberno-Latin literature of their own. ${ }^{3}$ In other words, learned culture in medieval Ireland was, effectively, bilingual.

Throughout the medieval period the Church was the one institution which was both international in character and cross-cultural in scope. Missionaries brought to the peoples they evangelized both a new religion and a new literate, learned culture in Latin. The medieval Church, therefore, filled roles played by present-day international, educational and cultural organizations. The Church's monastic schools were Europe's universities. 
They taught religious subjects such as Biblical exegesis and Holy Scripture, as well as secular subjects such as grammar, rhetoric, geometry and physics.

Later in this article I will survey some Irish clerics and scholars who worked outside of Ireland. But most importantly for present purposes, it is through the medieval Church that we can trace the interest of non-Irish "study abroad students" in Ireland's medieval universities, its monastic schools.

\section{Monastic Schools and Monastic Learning in Seventh-Century Ireland}

Several Irish monasteries developed into important centers of learning during the seventh century. The sites of monasteries mentioned below can still be located on modern road maps. A few sites are merely ruined stone walls, but several have survived as thriving modern communities.

The monastic school at Armagh (Ard Machae), Co. (County) Armagh, actively produced seventh-century hagiographical works about St. Patrick. ${ }^{4}$ Kildare (Cill Dara), Co. Kildare, promoted works about St. Brigit in the same century. ${ }^{5}$ Kildare also contained an important scriptorium. The monastic scholar Laidcenn mac Baíth Bannaig (d.661) worked at Clonfert-Mulloe (Cluain Ferta Mo-lua), Co. Laois. ${ }^{6}$ Cuimmíne Fota (d.662), another monastic scholar, worked in Clonfert (Cluain Ferta Brénainn), Co. Galway. ${ }^{7}$ Glendalough (Glenn dá locha), in the mountains of Co. Wicklow, and Clonmacnoise (Clúain mac Nóis), Co. Offaly, on the banks of the River Shannon, are the homes of manuscript compilations of religious and secular texts.

Columba (d.597), the first great wandering Irish monk, was educated, among other places, at the monastic school at Clonard (Cluain Iraird), Co. Meath. Clonard produced the scholar Ailerán (d.665). ${ }^{8}$ Subsequently, at least three scholars at the Carolingian palace schools on the continent made extensive use of Ailerán's work. They include the Englishman Alcuin (d.804), Walahfrid Strabo (d.849), and Hrabanus Maurus (d.856).

The monastic school at Iona in Scotland, founded by Columba, had a profound influence on Anglo-Saxon Northumbria. Although Iona is not geographically in Ireland, at this time and for several centuries subsequently, much of Scotland was culturally and politically Irish. A significant body of literature, both in Latin and Irish, was produced in seventh- 
century Iona.9 Several Anglo-Saxon kings came under the influence of Iona. King Oswald (634-42), educated and baptized among the Irish, is commemorated in Irish records as ardrí Saxan sóerdae "noble high-king of the English." ${ }^{10}$ Oswald invited Irish missionaries from Iona into his kingdom and even acted as interpreter for them (HE iii 3). ${ }^{11}$ Bede (d.735) stated that King Oswiu (642-70), brother of Oswald, having been educated among the Irish, thought that no learning could be better (HE iii 25). King Aldfrith (685-705), son of Oswiu, had an Irish mother and Bede stated that he was educated among the Irish. ${ }^{12}$ Aldfrith was renowned among the Irish for his scholarship and may have written texts in the Irish language. ${ }^{13}$

The Irish pilgrim Columbanus (d.615) had studied grammar, rhetoric, geometry and Holy Scripture in the monastery at Bangor (Bennchuir), Co. Down, in the mid-sixth century before he set out for the continent. ${ }^{14}$ Bangor was an important monastic literary center, using both Latin and the Irish language. Secular and religious texts were composed there. One of the most famous works is the so-called Antiphonary of Bangor, ${ }^{15}$ compiled between 680 and 691. It is not a true antiphonary, but it contains many fine Hiberno-Latin religious poems. Several early vernacular texts are associated with Bangor. Most of these texts are secular, or at least non-religious, in nature. Examples include Immram Brain "The Voyage of Bran," which deals with a voyage across the western ocean to the "otherworld," and stories about the Ulster prince Mongán mac Fiachnai (d.625), in which some of the episodes take place in Anglo-Saxon England. ${ }^{16}$ It has recently been argued that the Hisperica Famina "Western Sayings," which will be discussed in greater detail presently, may have originated in Bangor. ${ }^{17}$

\section{Evidence for Irish Monastic Schools from Anglo-Saxon Sources}

The Anglo-Saxon scholars and churchmen Aldhelm (d.709 as bishop of Sherbourne) and Bede (d.735 at Wearmouth-Jarrow), provide our clearest pictures of seventh-century Irish monastic education from an outsider's perspective. Both Aldhelm and Bede grew up in an England that, only a generation before, had been pagan. The conversion of Ireland, on the other hand, had begun in the fifth century. The twelfth-century his- 
torian, William of Malmesbury, stated that Aldhelm had had an Irish teacher named Máeldub. This seems likely since Aldhelm had served as abbot of Malmesbury, and Bede (writing c.731) had referred to Malmesbury as Maildubi urbs "Máeldub’s city" (HE v 18).

Bede himself was born into an Anglo-Saxon Northumbria only recently converted by the Irish. When Bede was between the ages of 13 and 33, Northumbria was ruled by the Irish-educated King Aldfrith. Bede's monastery of Wearmouth-Jarrow had benefited from the royal patronage of Aldfrith. Both Aldhelm and Bede were ecclesiastics, and their primary concern with religious education is obvious in their remarks about Irish monastic schools.

The high-point of Anglo-Saxon education in the late seventh century was the school run by Theodore and Hadrian at Canterbury. Bede boasted that the school at Canterbury provided students with a knowledge of both Latin and Greek ( $H E$ iv 2, v 8, v 20, v 23). Bishop Aldhelm himself had spent a few years there.

Nevertheless, Aldhelm felt the need to defend the school at Canterbury against the prestige of Irish schools. Aldhelm complained of English students flocking to Ireland rather than staying in England for their educations. Aldhelm queried rhetorically: "Why, I ask, is Ireland, whither assemble the thronging students by the fleet-load, exalted with a sort of ineffable privilege?"18

Aldhelm admitted that the "opulent and verdant country of Ireland is adorned, so to speak, with a browsing crowd of scholars," ${ }^{19}$ but he also showed that the traffic in eager students crossed the Irish Sea in both directions. Aldhelm described Theodore as being "hemmed in by a mass of Irish students, like a savage wild boar checked by a snarling pack of hounds." ${ }^{20}$ The venerable Theodore, however, was able to counter the challenging students "with the filed tooth of the grammarian." ${ }^{21}$

Aldhelm's complaints, cited above, are found in a letter addressed to an Englishman named Ehfridus (Heahfrith) who had returned to England after six years of study in Ireland "bursting with praise for learning." Aldhelm's letter to Ehfridus implied that grammar, geometry, physics and Biblical exegesis were available to the English students in Irish monastic schools in the seventh century. ${ }^{22}$

Aldhelm intimated that Ehfridus had spent time at Mayo of the Saxons (Mag nÉo na Saxan), ${ }^{23}$ a monastic site in the west of Ireland men- 
tioned by Bede and populated primarily by Englishmen (HE iv 4). Approximately thirty English monks had accompanied the Irish bishop Colmán to found a monastery in 668 at Inishboffin (Inis Bó Finne), an island off the west coast of Ireland. This occurred after the decision at the Council of Whitby in 664 which saw the end to Irishmen holding the bishopric of Lindisfarne in Northumbria (HE iii 25).

Mayo of the Saxons continued to thrive and attract Englishmen for more than a century after its foundation. For example, we know that in 732 an Englishman, Gerald, died as pontifex "bishop" there. In the late eighth century, the English scholar Alcuin (d.804) addressed a letter to the English monks at Mayo of the Saxons and mentioned their growing numbers, proving that Englishmen continued to travel as "study abroad students" to the west of Ireland. ${ }^{24}$ The monastery's presumed location is in the town of Mayo in the county of that name.

Bede discussed many Anglo-Saxon missionaries to the continental Germanic pagans who were trained in Ireland, probably at a monastic school at Ráth Melsigi in Co. Carlow, near the River Barrow. ${ }^{25}$ The location of this monastic school is now, unfortunately, destroyed by a gravel quarry. ${ }^{26}$ Bede's account emphasizes the importance of the Irish monastic schools to English ecclesiastical history and missionary efforts.

We know the names of many of these English "study abroad students" in Ireland. Willibrord was one such. After a successful mission he became archbishop of the Frisians in 696. He studied in Ireland between c.677-690 (HE iii 13). Another Englishman, Ecgberht, spent his entire adult life among the Irish. He lived to the venerable age of ninety ( $H E \mathrm{v}$ 9). He evidently attended and worked at the school in Ráth Melsigi between c.664-716. In 716 he went to Iona where he stayed until his death in 729 (HE iii 27).

Yet another Englishman, Wihtberht, lived and studied for many years in Ireland, probably at the school in Ráth Melsigi. After two unsuccessful years on mission in Frisia, he returned to Ireland, where he achieved prominence in Irish ecclesiastical circles ( $H E \mathrm{v} 9)$. Wihtberht's reputation among the Irish was such that he was celebrated in the ninthcentury Irish martyrology, Félire Óengusso. ${ }^{27}$

Two Englishmen, Black Hewald and White Hewald, trained at the school in Ráth Melsigi for their missions to the Old Saxons on the continent. Both suffered martyrdom at the hands of the continental pagans ( $H E$ 
v 10). Other Anglo-Saxons at Ráth Melsigi's school include the brothers Æthelhun and Æthelwine (the latter became bishop of Lindsey in England; $H E$ iii 27), and Chad, who became fifth bishop of the Mercians in England ( $H E$ iv 3).

Continentals, not just Englishmen, also studied at the Irish monastic schools. Bede related the story of Agilberht, a Gaul by birth, who became bishop of the Anglo-Saxon kingdom in Wessex (c.650 to 663). But before coming to England Agilberht "had spent a long time in Ireland for the purpose of studying the Scriptures" (HE iii 7). Political intrigues caused Agilberht eventually to leave Anglo-Saxon England and return to his native land, where for many years he served as bishop of Paris. Thus we see the career of a continental whose "study abroad" experience in Ireland prepared him for bishoprics in England and France.

We also know that one of the Merovingian monarchs, Dagobert II (d.679), "studied abroad" in Ireland. Dagobert, in his youth, was brought from France to Ireland as a political exile. Tradition has it that he received an education fit for a king, probably at the abbey in Slane (Sláine), Co. Meath. Slane was a wealthy monastery at this time. Its contacts extended throughout Ireland and onto the continent, specifically to St. Fursa's Irish monastery of Péronne in France. ${ }^{28}$

\section{Secular Learning in Irish Monastic Schools}

Bede and Aldhelm confirm that Irish monastic schools also produced secular learning despite their priorities of promoting religious study and ecclesiastical education. For example, Bede related an anecdote, attributed to the Englishman Willibrord, of "a scholar of Irish race who was well-read in literature but utterly uninterested and careless in the matter of his eternal salvation" (HE iii 13). In other words, Bede made it clear that a student at an Irish monastic school might be more concerned with the life of the mind than with the salvation of his soul.

Aldhelm had written a letter (sometime between 673 and 706) to an Englishman named Wihtfrith who intended to study in Ireland. Aldhelm warned Wihtfrith against the temptations of prostitutes. He also encouraged Wihtfrith to avoid the teachings about the Classical pagan deities, which he implied Wihtfrith would find abundantly in Irish schools 
instead of scriptural studies. ${ }^{29}$ The Hisperica Famina "Western Sayings" confirm that seventh-century Irish monastic scholars were acquainted with Classical deities and myths. ${ }^{30}$

We have no clear evidence of what secular topics were actively taught at Irish monastic schools. We do, however, have texts which suggest the secular topics that intrigued seventh-century monastic students. The Hisperica Famina has been mentioned and will be discussed presently. It was probably produced at the monastic school in Bangor. Other texts which may also have originated in Bangor include the Irish Immram Brain, "The Voyage of Bran," about a journey across the Western Ocean, and the stories about Mongán (d.625), a sort of Irish culture hero. ${ }^{31}$ Táin Bó Fraích, "The Cattle Raid of Fróech," is another Irish language text from this period. Fróech was a legendary hero who wooed the daughter of King Ailill and Queen Medb (Maeve). In order to win their daughter, Fróech promised to accompany Ailill and Medb's military expedition against the province of Ulster. ${ }^{32}$ The story of this expedition is told in the greatest of the early Irish epics, the Táin Bó Cúailnge "The Cattle Raid of Cooley." ${ }_{33}$ This epic tells how the Ulster hero, Cú Chulainn, withstood the invasion through a series of extraordinary single combats.

\section{A 'Study Abroad'Student's Life in Seventh-Century Ireland}

Bede (writing c.731) stated that during the decades of the 650s and 660s, Englishmen of all social classes, "both nobles and commons," left England in order to study abroad in Ireland (HE iii 27). Following his ecclesiastical predilections, Bede stated that these Englishmen came to pursue religious studies. However, he admitted that some of these Englishmen preferred to travel throughout Ireland, studying under various teachers rather than submitting to a strict monastic regime. Bede said that the "Irish welcomed them all gladly, gave them their daily food, and also provided them with books to read and with instruction, without asking for any payment" (HE iii 27). Bede's words read like an international educator's fondest dream-easy access to higher education in a foreign country without financial strain for the student, regardless of social class.

Many lines in the Hisperica Famina support Bede's statements and describe how foreign students were to be found among the Irish popula- 
tion. The Hisperica Famina are seventh-century texts written in an obscure and artificial Latin. Much of the vocabulary has been derived from Greek, Semitic, or Celtic language sources and provided with Latinate inflexional endings. Critics are not fully agreed on their purpose, but they would appear to be advanced school exercises in which the rhetorician describes a scene or phenomenon by deliberately using the most abstruse vocabulary possible. Many of these descriptions end in phrases which suggest that the rhetoricians are competing among themselves and composing under an imposed time limit.

The Hisperica Famina derive from a learned monastic milieu and mention God, prayer and a chapel. They are not religious writings, however, but rather are secular in tone and topic. They survive in several versions. The A-text, edited and translated by Michael Herren, ${ }^{34}$ is the most accessible version, and will be cited in translation for this discussion.

The most relevant section of the A-text is called the Lex Diei, "The Rule of the Day." Its opening describes the birds at sunrise in their search for food and proceeds with a pastoral scene including cattle, sheep, swine, horses and even dolphins. The humans described are the rural peasants who undertake herding and field labors. The students we first encounter are housed in large halls or dormitories among the peasants and not, apparently, in a monastic enclosure.

Like students everywhere, they claim to have been "burning the midnight oil" and complain of being awakened. They ask rhetorically, "Why do you oppress us with a thunderous crash of words and perturb the inner caverns of our ears with turgid speech? For we have devoted an entire measure of moonlight to studious wakefulness ... wherefore a feeling of drowsiness now overcomes us. ${ }^{35}$ The students nevertheless rise, wipe their eyes, and begin study of their vellum books: “... cleanse away nocturnal scum with fountain water. Remove the speckled volumes from the curved satchels and heed your rhetoric assignment." ${ }^{36}$

That the wandering students were foreigners and not Irish seems borne out by the following lines which precede their begging for food: "Who will ask these possessors to grant us their sweet abundance? For an Ausonian chain binds me; hence I do not utter good Irish speech." ${ }^{37}$ The editor would interpret the phrase "Ausonian chain" (ausonica catena) as the Latin language which the foreign students were able to use as a lingua franca in the confines of the monastic schools. But once they dispersed 
among the local population to beg food (as mendicants) they had to rely on the Irish language which they did not know, or knew only poorly, in order to communicate their needs. ${ }^{38}$

Bede's claim that the Irish provided foreign students with their daily food without asking for payment is supported by statements in the Lex Diei. For example, a rhetorician is made to say, "I have penetrated the remote farms of this region, and I seek out the charming inhabitants who feed the choirs of wandering scholars." ${ }^{39}$ The hospitality of the locals is stressed: "The charming townspeople apologize for having such meager supplies at hand. Cleave the victuals given to us with sharp knives, and set the wooden tables with heaps of food ...." ${ }^{40}$ Later in the text, a bombastic rhetorician expresses his appreciation by saying: "I hope from the deepest recess of my heart that the inhabitants may enjoy a prolonged and worthy life who have bestowed on us their honeyed abundance and have given us mounds of delicious food." 41

A scholar's articles, like book satchels and wax writing tablets, are also noted in the text. For example, the students at one point are exhorted to "Hang your white booksacks on the wall, set your lovely satchels in a straight line, so that they will be deemed a grand sight by the rustics..." 42 One section, De Taberna "On the Book Container," describes a book satchel, how it is made of sheepskin, and how a craftsman stretches the hide and shapes the leather container. ${ }^{43} \mathrm{~A}$ seventh-century Irish poem, which may have been composed by Adomnán (d.704), abbot of Iona, begins "A maccucáin, sruith in tíag" "Young boy, venerable is the satchel (that you take upon your back)." ${ }^{44}$ The Irish poem appears to describe such a book satchel and the contents, both concrete and ideal, that a young monastic scholar would find within it.

Another section, De Tabula "About the Writing Tablet," describes a waxen writing tablet which has carved and painted designs along its borders. The tablet, according to the Hisperica Famina, "contains the mysteries of rhetoric in waxen spheres." ${ }^{45}$ Seventh-century wax tablets have been recovered from a bog in Co. Antrim which still preserve verses of the Psalms inscribed on them. ${ }^{46}$

Other archaeological evidence concurs with the descriptions from the Hisperica Famina. The section De Oratorio "About the Chapel" describes a wooden chapel with a square foundation, vaulted ceilings and ornamented roof which contains an altar where the priests say mass. ${ }^{47}$ Both 
literary and archaeological evidence prove that seventh-century Irish churches tended to be timber constructions with square or rectangular foundations. ${ }^{48}$ On the other hand, the dwellings of the local inhabitants are always described as being round, tugoria turrita. ${ }^{49}$ Again, literary and archaeological evidence proves that typical seventh-century Irish dwellings were round..$^{50}$

Certain Irish social customs are also recounted in the Hisperica Famina. The early Irish bathed frequently and made provision for the bathing of guests as an act of hospitality. The A-text describes the custom of cleaning the feet of travelers: "Fill the steady hand basin with water and wash your dirty feet with flowing draughts; wipe clean your muddy soles with the clear liquid," 51 and again: "pour a clear draught from the wooden tank and wash your dirty feet." ${ }^{2}$ The early Irish had a highly developed vocabulary for bathing, with separate words for washing the feet, the hands, hair, or immersing the entire body. ${ }^{53}$ Osaic was the Old Irish word for washing the feet. As can be seen, the Hisperica Famina accurately portrayed the seventh-century world of these "study abroad students" in Ireland.

\section{Irish Scholars and CIerics Beyond Ireland's Shores}

One of the best ways to gauge the excellent quality of the Irish monastic schools is to survey some of the Irish clerics and intellectuals who were educated in them but exercised their talents abroad. Many Irish clerics went to the Merovingian (pre-800) kingdoms on the continent as missionaries to convert pagans or to strengthen the Church's organizations, including monastic schools. Irish scholars that we find in the Carolingian (post-800) courts are often intellectuals seeking the stimulation of the court schools. The presence of these Irish clerics and scholars can be traced through Scotland, England, Wales, France, Italy, Belgium, Germany, Austria and beyond.

The frequency with which these Irish churchmen undertook voluntary exile shows that what is known as the Irish "Diaspora" of recent centuries is not a new phenomenon. All but one of the following ultimately settled somewhere on the continent.

Columba is the first of the great wandering Irish monks. Tradition 
states that he left Ireland as a form of penance. He crossed the sea to Scotland where he established the island monastery of Iona c.563. Legend has it that Columba trained as a poet before becoming a cleric. ${ }^{54}$ The Life of Columba, written by Adomnán, abbot of Iona from 679-704, is an important primary source for the period. ${ }^{55}$ Iona evangelized Anglo-Saxon Northumbria beginning in the decade of the 630s. As has been mentioned, the Northumbrian kings Oswald, Oswiu, and Aldfrith received their educations at Iona or under its sphere of influence. Their reigns helped lay the foundations for a "Northumbrian Golden Age" in the late seventh and early eighth centuries. Columba died in 597.

Columbanus, who trained at the monastery of Bangor, Co. Down in Northern Ireland, is the first of the great pilgrims to the continent. He left Bangor c.590 and travelled with twelve companions to the Merovingian kingdoms in the region of Burgundy, France, where he founded monasteries at Annagray, Fontaines, and Luxeuil. His most famous foundation was Bobbio in northern Italy. Bobbio served as a stopover for pilgrimages to Rome, and continued to be a center of Irish influence for several centuries. ${ }^{56}$ Columbanus left a surprisingly large body of writings, which include letters (some to popes), monastic rules, penitentials and poems. ${ }^{57}$ An Italian monk named Jonas wrote a Life of Columbanus c.640.58 Columbanus died in 615.

Gall was one of Columbanus' companions to the continent, but he was unable to continue the journey to Italy with Columbanus because of illness. Gall, therefore, remained behind and went on to found the monastery of St. Gallen near Lake Constance in Switzerland. His impact can be gauged by the fact that several Lives were written about him. Among his biographers are such noted ninth-century intellectuals as Walahfrid Strabo (c.833) and Nokter Balbulus (c.885). ${ }^{59}$ Gall died c.630.

Fursa is another Irish cleric to go to the continent, but first he established a monastery among the Anglo-Saxons of East Anglia c.632. Within a few years he left England and founded a monastery in Picardy, north of Paris. It was known as Perrona Scottorum "Péronne of the Irish," and became, like Columbanus' Bobbio in northern Italy, a European center of Irish influence. Like Columbanus, Fursa travelled with Irish companions, several of whom became famous in their own right. Cellán (d.706), an Irish abbot of Péronne, and Aldhelm (d.709), the Anglo-Saxon scholar and churchman, corresponded with each other. ${ }^{60}$ The medieval 
writings about Fursa are also extensive. ${ }^{61}$ Anglo-Saxon authors who wrote about Fursa include Bede (c.731; HE iii 19) and Ælfric (d.c.1012). Fursa died c. 650 .

Kilian is the most successful of the Irish missionaries to Germany. $\mathrm{He}$ is especially revered at Würzburg. Interlinear Irish glosses in Latin manuscripts preserved at Würzburg helped nineteenth-century philologists reconstruct the Old Irish language. We know that Kilian spent approximately two years in Rome, probably around 686/7. He was martyred shortly after his return from Rome to Würzburg c.689. ${ }^{62}$

In 743 the Merovingian king Pippin sent the Irishman Virgil to Bavaria after putting down an insurrection there. Virgil worked in the region with other Irishmen, and by 755 he was consecrated bishop at Salzburg, Austria. Virgil is remembered for the conflict between himself and the English missionary Boniface. The latter evidently accused Virgil to the Pope of belief in the doctrine of the antipodes, "that there are another world and other men under the earth, and another sun and moon." No action was ever taken against Virgil for this charge. The Englishman Alcuin (d.804), who was famous in the Carolingian palace schools, wrote a poem about Virgil, who died in $784 .^{63}$

Dicuil is one of the Irishmen who had the greatest intimacy with the Carolingian court. We know little about his background other than that he was active in the court schools by $814 .{ }^{64}$ In 825 his most famous work, De Mensura Orbis Terrae, "On the Measurement of the Earth," appeared. ${ }^{65}$ In this early treatise on world geography he related the account of an Irish pilgrim to the Holy Land which included a description of the "barns of Joseph" on the Nile, that is, the pyramids in Egypt. He discussed the Irish hermits who sailed to isolated islands in the North Atlantic and used eyewitness accounts of these same Irish hermits in Iceland (before the arrival of the Norse) to describe the midnight sun. We have no firm date for Dicuil's death.

Sedulius Scottus is one of the most widely known of the Irish scholars in the Carolingian courts. Modern scholars usually speak of "the Circle of Sedulius" since Sedulius, like all of the Irish mentioned, travelled as part of a group. ${ }^{66}$ We know practically nothing of Sedulius until he reached the continent. By 848 he had arrived at Liège, Belgium. It has been suggested that he was a member of an embassy sent from the Irish high-king, Máel Sechlainn, to the court of Charles the Bald. The 
entourage may have stopped off in Wales at the court of King Rhodri Mawr. Sedulius' most famous work is De Rectoribus Christianis, "On Christian Rulers." ${ }^{67}$ It belongs to the genre known as specula principum, "mirrors for princes," intended as instruction for rulers. One of its main tenants is that the ruler is appointed by God to protect and assist the Church. The Anglo-Saxon homilist, Wulfstan (d.1023), relied on Sedulius' work in writing his own "Institutes of Polity." By 874 Sedulius disappeared from history.

Johannes Scottus Eriugena is the most widely respected as an original thinker of the Irish scholars in Carolingian France. He was a contemporary of Sedulius Scottus. Bertrand Russell called Johannes "the most astonishing person of the ninth century" and went on to say that "he was an Irishman, a Neo-platonist, an accomplished Greek scholar, a Pelagian, a pantheist." ${ }^{68}$ Like Sedulius, we know practically nothing of Johannes, except through the works he produced on the continent. The name he is known by is tautological. "Scottus" means "an Irishman" and "Eriugena" means "born in Ireland." He must have arrived at the palace school of Laon, northeast of Paris, by 845 . By 851 he produced his De Praedestinatione, "On Predestination," in which he defended free will, but he relied primarily on philosophy rather than divine revelation for its defense. ${ }^{69}$ His most famous work is De Divisione Naturae, "On the Division of Nature. ${ }^{{ }^{70}}$ It is the first great philosophical production of medieval Western Europe. His knowledge of Greek, and his reliance on Greek texts in the original, is unsurpassed by any of his contemporaries. The source of his knowledge has yet to be satisfactorily explained. After about 870 we hear nothing more of Johannes.

The above brief survey shows that Irish clerics and scholars who trained in Ireland left their marks well beyond Ireland's shores. These native Irishmen studied at the same Irish monastic schools that accepted "study abroad students."

\section{Eclecticism and Being At Home Abroad}

The dynamic eclecticism of early Irish learned culture should be evident from this survey. Irish scholars were famed at home and abroad throughout the Middle Ages. Those Irishmen who went abroad brought with them, in essence, a bit of Ireland. Irish monastic schools also took in 
foreign scholars from abroad. The majority of "study abroad students" in medieval Ireland, for whom we have clear records, came from AngloSaxon England.

Modern Ireland is again active in the international exchange of students and scholars. Foreign students studying abroad in Ireland today, whether they come from North America, Europe, or elsewhere, still find a hospitable Irish welcome. They also find the same literary dynamism and eclecticism as existed in medieval Ireland. In this century alone James Joyce's Ulysses has proven to be one of the most influential novels ever written. His Finnegan's Wake provides abundant proof of continuing eclecticism. Ireland has also produced four Nobel Literary Prize winners this century: W.B. Yeats (1923), George Bernard Shaw (1925), Samuel Beckett (1969), and Seamus Heaney (1995).

Like many medieval Irish scholars, each of these five modern Irish writers has spent extended periods outside of Ireland, sometimes writing in other languages, and often earning their living as teachers. Since these modern writers all write in English, their influence has been worldwide. Nevertheless, they remain distinctly Irish while displaying universality. Likewise, medieval Irish scholars helped disseminate a unified culture through the Latin of the Church, while at the same time maintaining a special Irish essence.

\section{Notes}

1 For purposes of this article I rely exclusively on the edition by Michael W. Herren, ed. and trans., The Hisperica Famina: I. The A-Text, a New Critical Edition with English Translation and Philological Commentary (Toronto: Pontifical Institute of Mediaeval Studies, 1974).

2 For a good overview, see J.E. Caerwyn Williams and Patrick F. Ford, The Irish Literary Tradition (Cardiff: U of Wales P; Belmont, MA: Ford \& Bailie, 1992) and Robin Flower, The Irish Tradition (Oxford: Clarendon Press, 1947). The intellectual life of medieval Ireland has recently captured the popular imagination. See the simplistic but entertaining bestseller by Thomas Cahill, How the Irish Saved Civilization, the Untold Story of Ireland's Heroic Role from the Fall of Rome to the Rise of Medieval Europe (New York: Doubleday; London: Hodder \& Stoughton, 1995). 
3 Two works by Helen Waddell are backed by solid scholarship yet provide the non-specialist with an excellent introduction to this period. See The Wandering Scholars (London: Constable, 1927) and Medieval Latin Lyrics 4th ed. (1933; London: Constable, 1947).

4 Tírechán and Muirchú are Patrician hagiographers who wrote in the last quarter of the seventh century. See Ludwig Bieler, ed. and trans., The Patrician Texts in the Book of Armagh, Scriptores Latini Hiberniae X (Dublin: Dublin Institute for Advanced Studies, 1979). Michael Lapidge and Richard Sharpe, A Bibliograpby of Celtic-Latin Literature 400-1200 (Dublin: Royal Irish Academy, 1985) 83 §301 (Tírechán), 84 §303 (Muirchú).

5 For a translation and evaluation of Brigit's earliest surviving Life, see Sean Connolly, "Cogitosus's Life of St Brigit, Content and Value," Journal of the Royal Society of Antiquaries of Ireland 117 (1987): 5-27. Lapidge and Sharpe $84 \$ 302$.

6 Colin Ireland, "Aldfrith of Northumbria and the Learning of a Sapiens," in A Celtic Florilegium, Studies in Memory of Brendan O Hebir, ed. Kathryn A. Klar, Eve E. Sweetser and Claire Thomas (Lawrence, Mass.: Celtic Studies Publications, 1996) 63-77, at pp. 64-5. Lapidge and Sharpe 80-81 $\$ 293-4$.

7 Ireland, "Aldfrith and Learning" 65-6. Lapidge and Sharpe 79-80 $\S 292$.

8 Aidan Breen, ed. and trans., Ailerani Interpretatio Mystica et Moralis Progenitorvm Domini Iesv Christi (Dublin: Four Courts Press, 1995). Ireland, "Aldfrith and Learning" 67. Lapidge and Sharpe 82-3 §§ 299300 .

9 For a sense of the variety of texts produced at Iona during the seventh century, see Thomas Owen Clancy and Gilbert Márkus, ed. and trans., Iona: The Earliest Poetry of a Celtic Monastery (Edinburgh: U. Edinburgh Press, 1995).

10 Whitley Stokes, ed., Félire Óengusso Céli Dé: The Martyrology of Oengus the Culdee (1905; Dublin: Dublin Institute for Advanced Studies, 1984) 174.

11 One of our best sources for Britain and Ireland in this period is Bede's Historia Ecclesiastica (hereafter referred to as $H E$ ). The best edition is Bertram Colgrave and R.A.B. Mynors, ed., Bede's Ecclesiastical History of the English People (Oxford: Clarendon Press, 1969). 
12 Colin Ireland, "Aldfrith of Northumbria and the Irish Genealogies,” Celtica 22 (1991): 64-78.

13 Ireland, "Aldfrith and Learning," 73-6. See my forthcoming edition of Old Irish maxims attributed to Aldfrith under his Irish name Flann Fína: Old Irish Wisdom Attributed to Aldfrith of Northumbria, an Edition of Briathra Flainn Fhina maic Ossu, Medieval and Renaissance Texts and Studies CCV (Tempe: Arizona Center for Medieval and Renaissance Studies, 1999).

14 John Ryan SJ, Irish Monasticism, Origins and Early Development 2nd ed. (1972; Dublin: Four Courts Press, 1992) 378; G.S.M. Walker, ed. and trans., Sancti Columbani Opera, Scriptores Latini Hiberniae II (Dublin: Dublin Institute for Advanced Studies, 1957) lxvi-lxxii.

15 An antiphonary is a collection of antiphons, short verses sung by one side of a choir in response to those sung by the other. They are usually based on, or in response to, Biblical verses such as Psalms, canticles, etc.

16 Kuno Meyer, The Voyage of Bran Son of Febal to the Land of the Living (1895; Felinfach: Llanerch, 1994).

17 Jane Stevenson, "”Bangor and the Hisperica Famina," Peritia 6-7 (1987-88): 202-216.

18 Michael Lapidge and Michael Herren, trans., Aldhelm, the Prose Works (Ipswich: D.S. Brewer; Totowa, N.J.: Rowman and Littlefield, 1979) 163.

19 Lapidge and Herren 163.

20 Lapidge and Herren 163.

21 Lapidge and Herren 163.

22 Lapidge and Herren 161-2.

23 Lapidge and Herren 145, 161.

24 See Stephen Allott, Alcuin of York c. A.D. 732 to 804 - His Life and Letters (York: William Sessions, 1974) 44-5 §33.

25 See Michael Richter, "Die irische Hintergrund der angelsächsischen Mission," in Die Iren und Europa im früheren Mittelalter, ed. Heinz Löwe, 2 vol. (Stuttgart: Klett-Cotta, 1982) 120-37.

26 Dáibhí Ó Cróinín, "Rath Melsigi, Willibrord, and the Earliest Echternach Manuscripts," Peritia 3 (1984): 17-49.

27 Colin Ireland, "Some Analogues of the O.E. Seafarer from Hiberno-Latin Sources," Neuphilologische Mitteilungen 92.1 (1991): 9 and 
notes 38, 39 .

28 J. M. Picard, "Church and Politics in the Seventh Century: The Irish Exile of King Dagobert II," in Ireland and Northern France A.D. 600850, ed. Jean-Michel Picard (Dublin: Four Courts Press, 1991) 27-52.

29 Lapidge and Herren 154-5.

30 Herren 39-44.

31 For Immram Brain and the Mongán stories, see Meyer, Voyage of Bran.

32 For a translation of this tale, see Jeffrey Gantz, trans., Early Irish Myths and Sagas (Harmondsworth: Penguin Books, 1981) 113-26 "The Cattle Raid of Fróech.” The standard edition is by Wolfgang Meid, ed., Táin Bó Fraích (Dublin: Dublin Institute for Advanced Studies, 1967).

33 For a translation, see Thomas Kinsella, trans., The Tain, Translated from the Irish Epic Tain Bo Cuailnge (London and New York: Oxford UP, 1970). The standard editions are by Cecile O'Rahilly, ed. and trans., Táin Bó Cúailnge, Recension I (Dublin: Dublin Institute for Advanced Studies, 1976); and idem, ed. and trans., Táin Bó Cúalnge from the Book of Leinster (Dublin: Dublin Institute for Advanced Studies, 1967).

34 See note 1 . See also Lapidge and Sharpe 93-6 $\$$ 325-38.

35 Herren 78-81 lines 205-09.

36 Herren 80-81 lines 212-14.

37 Herren 84-5 lines 271-4.

38 Herren 34-5.

39 Herren 80-81 lines 229-31.

40 Herren 84-5 lines 276-9.

41 Herren 90-91 lines 338-41.

42 Herren 84-5 lines 262-4.

43 Herren 104-07 lines 513-30.

44 James Carney, “A maccucáin, sruith in tíag,” Celtica 15 (1983): 25-41.

45 Herren 106-07 line 544.

46 For an illustration of one of these tablets, see Timothy O'Neill, The Irish Hand, Scribes and their Manuscripts from the Earliest Times (Portlaoise: Dolmen Press, 1984) 57. See also, Nancy Edwards, The Archaeology of Early Medieval Ireland (London: B. T. Batsford, 1990) 148.

47 Herren 108-09 lines 547-60.

48 Edwards 122-4. 
49 Herren 164 for discussion.

50 Edwards 22-7.

51 Herren 82-3 lines 259-61.

52 Herren 88-9 lines 326-7.

53 A. T. Lucas, "Washing and Bathing in Ancient Ireland," Journal of the Royal Society of Antiquaries of Ireland 95 (1965): 65-114.

54 To appreciate how a body of literature can accrue to the reputation of a great saint such as Columba, see James F. Kenney, The Sources for the Early History of Ireland: Ecclesiastical, an Introduction and Guide (1929; Dublin: Pádraic Ó Táilliúir, 1979) 264-5 § 91, 422-42 esp. pp. 436-40 § 220 .

55 Alan Orr Anderson and Marjorie Ogilvie Anderson, ed. and trans., Adomnan's Life of Columba, rev. ed., (Oxford: Clarendon Press, 1991). Lapidge and Sharpe $86 \$ 305$.

56 For an overview, see Pierre Riché, Education and Culture in the Barbarian West, trans. John J. Contreni (Columbia: U. of S. Carolina Press, 1976) 324-36.

57 Walker, Sancti Columbani Opera. Lapidge and Sharpe 165-8 $\S$ 639-42. The attribution of several poems to Columbanus is no longer accepted.

58 Kenney 203-5 § 48; Walker ix-xxxiv.

59 Kenney 206-8 §50.

60 Lapidge and Herren 149, 167. Lapidge and Sharpe $168 \S 643$.

61 Kenney 500-510, esp. 501-03 § 296.

62 Kenney 511-13.

63 Kenney 523-6. For writings by Virgil, see Lapidge and Sharpe $169-70 \$ 647$.

64 Kenney 545-8. See also Lapidge and Sharpe 174-5 $\$$ 660-64.

65 J. J. Tierney, ed. and trans., Dicuili Liber de Mensura Orbis Terrae, Scriptores Latini Hiberniae VI (Dublin: Dublin Institute for Advanced Studies, 1967).

66 Kenney 553-5.

67 Kenney 564-5 $§ 372$. See also Lapidge and Sharpe 177-80 $\$$ 672-86.

68 Bertrand Russell, A History of Western Philoshopy (New York: Simon and Schuster, 1945) 400. For a more recent assessment, see Dermot 
Frontiers: The Interdisciplinary Journal of Study Abroad

Moran, "Nature, Man and God in the Philosophy of John Scottus Eriugena," in The Irish Mind, Exploring Intellectual Traditions, ed. Richard Kearny (Dublin: Wolfhound Press, 1985) 91-106.

69 Kenney $575-7 \S 381$.

70 Kenney 583-5 § 391. See also Lapidge and Sharpe 183-92 $\S$ $695-713$. 